\title{
Analysis of sensitivity of a company's financial sustainability to random factors
}

\author{
Ilona Avlasenko ${ }^{1, *}$, Lyudmila Avlasenko ${ }^{1}$, Isa Peshkhoev ${ }^{1}$, Yuri Podkolzin ${ }^{1}$, and Oksana \\ Savelyeva ${ }^{1}$ \\ ${ }^{1}$ Don State Technical University, 1, Gagarin Square, 344003, Rostov-on-Don, Russia
}

\begin{abstract}
In this article the problem of influence of accidental changes of financial indicators of enterprise activity (equity, long-term/short-term borrowed capital, reserves and costs, etc.) caused by uncertainty of market conditions on values of indicators of financial stability is considered. The study is conducted on the basis of the assumption that the studied financial indicators of the enterprise are random values with a normal law of distribution. To estimate the distribution parameters of these random values, statistical data on the values of the financial indicators of the enterprise for previous years are used. Following estimates of probabilities of financial stability levels were built: absolute stability, normal stability, unstable state and crisis financial state. With the help of statistical modeling, numerical experiments were conducted in order to determine the level of financial condition and conclusions were formulated on the impact on the financial condition of the enterprise of the parameters of the distribution of probabilities of random variables - indicators of the financial and economic activity of the enterprise.
\end{abstract}

\section{Introduction}

To make a correct decision on management of financial and economic activity of the enterprise in conditions of uncertainty of market conditions, the task of forecasting of financial stability level is urgent (absolute sustainability, normal sustainability, unsustainable condition and crisis financial condition) taking into account that the main financial indicators for assessing financial sustainability (equity, long-term borrowed capital, short-term borrowed capital, reserves and costs) can only be known at the end of the current period.

In work [1] a simulation model of enterprise growth is built. It is assumed that the annual return on working capital and the loan rate are random values with a normal distribution, the amount of borrowed capital does not exceed the amount of own working capital. With a given amount of equity at the beginning of the period, its dependence on time is built as a random process. The parameters of random variables based on the processing of statistical data on the previous activities of this enterprise were estimated. The implementation of a random process is statistically modeled. Using statistical tests, the

\footnotetext{
*Corresponding author: avlas333@mail.ru
} 
implementation of the random function of growth of equity was built and the probability of bankruptcy was estimated as the relative frequency of cases when the random function accepts a negative value.

Work [2] applies different approaches to the evaluation of an investment project in conditions of uncertainty, when such project parameters as future returns and discount rates are set approximately or unknown. The results of the project evaluation are analyzed with the following approaches: the use of fuzzy sets; application of probability theory. The conditions of applicability and validity of the approaches under consideration are discussed.

Work [3] considers theoretical economic and mathematical models based on real data for compliance with empirical dynamics. An analysis of the financial condition of enterprises of the military-industrial complex of the Russian Federation is carried out on the basis of retro-data in the period from 2004 to 2012. Two financial analysis factors are used to characterize the financial condition of the organization: the current liquidity ratio and the equity ratio. Models were built for forecasting and assessing the financial sustainability of defense industry enterprises based on the dynamics of coefficient increases.

\section{Wording of the problem}

Let us consider the problem of rapid forecasting of the financial stability level of a small enterprise based on the analysis of statistical data on the financial and economic indicators of its economic activity in conditions of uncertainty. This problem often arises before the end of the current period, when the future totals of the indicators are unknown: equity, long-term and short-term borrowed capital, reserves and costs. It is proposed to use methods of probability theory and mathematical statistics, to consider the investigated financial indicators random values with the normal law of probability distribution. At the same time, to estimate distribution parameters, use their point estimates (sample average and corrected variance), obtained on the basis of statistical data on their values for previous years.

\section{Probabilistic assessment of financial sustainability}

According to the results of a certain period (year, month, quarter), an enterprise can be in one of four levels of financial states: absolute stability, normal stability, unstable state, crisis financial state. Let's take a look at how to measure your financial health.

The financial assets of the enterprise are measured from the balance sheet by three indicators [4.5]:

1) OWC's own working capital.

2) Working capital

$\mathrm{WC}=\mathrm{OWC}+\mathrm{LDC}$

where LDC (long-term debt capital) is long-term liabilities.

3) Total funding sources

$\mathrm{TFS}=\mathrm{OWC}+\mathrm{LDC}+\mathrm{SDC}$

where SDC (short-term debt capital) is short-term liabilities.

These three groups of funds are compared with the following value: stocks and costs $\mathrm{SaC}$.

Calculations are entered in table 1 and a three-pronged measure of the financial situation is determined according to the following rule:

1. If $\mathrm{OWC}-\mathrm{SaC}>0$, WC $-\mathrm{SaC}>0$, TFS $-\mathrm{SaC}>0$ - the company has absolute financial stability (three-component indicator of the situation - $(1 ; 1 ; 1)$ ) 
2. If $\mathrm{OWC}-\mathrm{SaC}<0, \mathrm{WC}-\mathrm{SaC}>0$, $\mathrm{TFS}-\mathrm{SaC}>0$ - the company has normal financial stability, guaranteeing solvency (three-component indicator of the situation - $(0 ; 1 ; 1)$ ).

3. If $\mathrm{OWC}-\mathrm{SaC}<0, \mathrm{WC}-\mathrm{SaC}<0$, TFS $-\mathrm{SaC}>0$ is an unstable financial condition of the enterprise associated with a violation of solvency (three-component indicator of the situation - $(0 ; 0 ; 1))$.

4. If $\mathrm{OWC}-\mathrm{SaC}<0, \mathrm{WC}-\mathrm{SaC}<0$, TFS $-\mathrm{SaC}<0-$ this indicates a crisis financial condition of the organization (three-component indicator of the situation - $(0 ; 0 ; 0)$ ).

The three-component indicator reflects the level of financial stability of the enterprise.

Table 1 shows an example of how indicators are calculated to determine the level of financial sustainability. We see that the company at the end of 2018 had normal financial stability, and at the end of 2019 was in precarious financial condition.

Table 1. Analysis of the financial condition of the enterprise

\begin{tabular}{|l|c|c|c|}
\hline Key Figures & Indicators & $\mathbf{3 1 . 1 2 . 2 0 1 8}$ & $\mathbf{3 1 . 1 2 . 2 0 1 9}$ \\
\hline 1. Totalinventoryandcosts & $S a C$ & 19168 & 18511 \\
\hline 2. Own Working Capital & $O W C$ & -117051 & -116380 \\
\hline 3. Working capital & $\begin{array}{c}W C=O W C+ \\
L D C\end{array}$ & 31635 & 12506 \\
\hline 4. Total funding sources & $\begin{array}{c}T F S=O W C+ \\
L D C+S D C\end{array}$ & 238973 & 237020 \\
\hline $\begin{array}{l}\text { 5. Surplus/shortage of own } \\
\text { working capital }\end{array}$ & $O W C-S a C$ & -136219 & -134891 \\
\hline $\begin{array}{l}\text { 6. Surplus/lack of working } \\
\text { capital }\end{array}$ & $W C-S a C$ & 12467 & -6005 \\
\hline $\begin{array}{l}\text { 7. Surplus/lack of Funding } \\
\text { Sources }\end{array}$ & $T F S-S a C$ & 219805 & 218509 \\
\hline $\begin{array}{l}\text { 8. Three-component } \\
\text { indicator of the financial } \\
\text { situation }\end{array}$ & & $(0 ; 1 ; 1)$ & $(0 ; 0 ; 1)$ \\
\hline
\end{tabular}

Assume that inventory and cost values, equity, long-term and short-term liabilities ( $\mathrm{SaC}$, OWC, LDC, and SDC) are random values with a normal probability distribution law with known mathematical expectations $\mathrm{M}[\mathrm{SaC}], \mathrm{M}$ [OWC], $\mathrm{M}$ [LDC], $\mathrm{M}$ [SDC], and variances $\mathrm{D}[\mathrm{SaC}], \mathrm{D}[\mathrm{oooC}]$ Then we can write, using the properties of mathematical expectation and variance of random variable [6], formulas for mathematical expectation and variance of surplus/disadvantages in rows 5,6 and 7 of Table 1 :

$\mathrm{M}[\mathrm{OWC}-\mathrm{SaC}]=\mathrm{M}[\mathrm{OWC}]-\mathrm{M}[\mathrm{SaC}]$

$\mathrm{M}[\mathrm{WC}-\mathrm{SaC}]=\mathrm{M}[\mathrm{OWC}]+\mathrm{M}[\mathrm{LDC}]-\mathrm{M}[\mathrm{SaC}]$

$\mathrm{M}[\mathrm{TFS}-\mathrm{SaC}]=\mathrm{M}[\mathrm{OWC}]+\mathrm{M}[\mathrm{LDC}]+\mathrm{M}[\mathrm{SDC}]-\mathrm{M}[\mathrm{SaC}]$

$\mathrm{D}[\mathrm{OWC}-\mathrm{SaC}]=\mathrm{D}[\mathrm{OWC}]+\mathrm{D}[\mathrm{SaC}]+2 \operatorname{cov}[\mathrm{OWC}, \mathrm{SaC}]$

$\mathrm{D}[\mathrm{WC}-\mathrm{SaC}]=\mathrm{D}[\mathrm{OWC}]+\mathrm{D}[\mathrm{LDC}]+\mathrm{D}[\mathrm{SaC}]+$

$+2 \operatorname{cov}(\mathrm{OWC}, \mathrm{LDC})+2 \operatorname{cov}(\mathrm{OWC}, \mathrm{SaC})+2 \operatorname{cov}(\mathrm{LDC}, \mathrm{SaC})$

$\mathrm{D}[\mathrm{TFS}-\mathrm{SaC}]=\mathrm{D}[\mathrm{OWC}]+\mathrm{D}[\mathrm{LDC}]+\mathrm{D}[\mathrm{SDC}]+\mathrm{D}[\mathrm{SaC}]+$

$+2 \operatorname{cov}(\mathrm{OWC}, \mathrm{LDC})+2 \operatorname{cov}(\mathrm{OWC}, \mathrm{SDC})+2 \operatorname{cov}(\mathrm{OWC}, \mathrm{SaC})+$

$+2 \operatorname{cov}(\mathrm{LDC}, \mathrm{SDC})+2 \operatorname{cov}(\mathrm{LDC}, \mathrm{SaC})+2 \operatorname{cov}(\mathrm{SDC}, \mathrm{SaC})$

It is now possible to calculate the positive probabilities of excess/disadvantages, since these random variables have a normal distribution law. At the same time, mathematical expectation and variance should be replaced by point estimates, that is, selective average and selective corrected variances, which are determined from statistical data.

Similar formulas above are valid for selective mean and selective variance, so we will not write them out. 


\section{Results}

Let us consider the results of application of the proposed method of estimation of probabilities of positivity of surplus/deficiencies. For calculations we use Excel spreadsheet software and built-in mathematical statistics functions [7].

Example 1. Sample values of financial indicators and their sample averages and variances are shown in Table 2.

Table 2. Sample Financial Key Figures Example 1

\begin{tabular}{|c|c|c|c|c|}
\hline $\boldsymbol{k}$ & $\boldsymbol{S a}_{\boldsymbol{k}}$ & $\boldsymbol{O} \boldsymbol{W C}_{\boldsymbol{k}}$ & $\boldsymbol{L D C}_{\boldsymbol{k}}$ & $\boldsymbol{S D C}_{\boldsymbol{k}}$ \\
\hline 1 & 239.55 & 73.02 & 73.20 & 102.02 \\
\hline 2 & 245.04 & 91.51 & 60.65 & 98.61 \\
\hline 3 & 243.61 & 74.14 & 61.92 & 93.03 \\
\hline 4 & 238.56 & 88.38 & 63.51 & 100.94 \\
\hline 5 & 234.18 & 71.79 & 65.95 & 83.80 \\
\hline 6 & 230.90 & 81.62 & 69.85 & 91.10 \\
\hline 7 & 236.73 & 90.04 & 70.82 & 88.43 \\
\hline 8 & 237.89 & 91.12 & 67.40 & 80.79 \\
\hline 9 & 246.66 & 71.13 & 55.06 & 103.82 \\
\hline 10 & 246.33 & 92.53 & 58.51 & 69.20 \\
\hline $\begin{array}{c}\text { Selective } \\
\text { average }\end{array}$ & 239.94 & 82.53 & 64.69 & 91.17 \\
\hline $\begin{array}{c}\text { Meansquare } \\
\text { value }\end{array}$ & 5.34 & 9.14 & 5.79 & 10.98 \\
\hline
\end{tabular}

Table 3 shows the covariance matrix calculated from Table 2.

Table 3. Covariancematrix

\begin{tabular}{|l|c|c|c|c|}
\hline & $\boldsymbol{S a C}$ & $\boldsymbol{O W C}$ & $\boldsymbol{L D C}$ & $\boldsymbol{S D C}$ \\
\hline $\mathrm{SaC}$ & 25.6829599 & & & \\
\hline OWC & 21.77726058 & 75.17552 & & \\
\hline LDC & -0.169354923 & -10.4954 & 30.20401592 & \\
\hline SDC & -19.76900787 & 4.592895 & 13.77753499 & 108.4072 \\
\hline
\end{tabular}

Table 3 shows the results of calculation of probabilities of financial stability levels.

Table 4. Results of calculation of probabilities of financial stability levels for example 1.

\begin{tabular}{|c|c|c|c|}
\hline Financial in dicators & 窇 & 总总 & \multirow{7}{*}{ 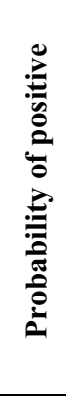 } \\
\hline Inventory and costs $\mathrm{SaC}$ & 239 & 5.34 & \\
\hline Own Working Capital $O W C$ & 82 & 9.14 & \\
\hline long-term liabilities $L D C$ & 64 & 5.79 & \\
\hline Short term liabilities $S D C$ & 91 & 10.00 & \\
\hline Working capital WC & 147 & 9.80 & \\
\hline All funding sources TFS & 238 & 15.26 & \\
\hline Surplus/shortage of own working capital OWC $-\mathrm{SaC}$ & -157 & 12.47 & 0 \\
\hline Surplus/lack of working capital WC- $\mathrm{SaC}$ & -92 & 12.96 & 0 \\
\hline Surplus/lack of funding sources $T F S-S a C$ & -1 & 16.28 & 0.47 \\
\hline
\end{tabular}


For Example 1, we have the following conclusion.

Judging by the average values of financial indicators, we have negative values of all sources of financing of inventory and costs. Table 3 shows that the probability of an unsustainable financial situation by the end of the current period (three-pronged financial situation $(0 ; 0 ; 1))$ is 0.47 , while the probability of a crisis financial condition is 0.53 .

Probabilities of financial situations $(1 ; 1 ; 1)$ and $(0 ; 1 ; 1)$ close to zero.

Example 2. Let us consider the selected financial data presented in table 5.

Table 5. Sample Financial Key Figures Example 2

\begin{tabular}{|c|c|c|c|c|}
\hline $\boldsymbol{k}$ & $\boldsymbol{S a C}$ & $\boldsymbol{O W C}$ & $\boldsymbol{L D C}$ & $\boldsymbol{S D C}$ \\
\hline 1 & 154.02 & 71.70 & 61.07 & 78.49 \\
\hline 2 & 156.36 & 91.12 & 57.24 & 104.60 \\
\hline 3 & 162.21 & 94.89 & 55.69 & 84.21 \\
\hline 4 & 157.48 & 80.43 & 60.14 & 87.66 \\
\hline 5 & 157.97 & 75.24 & 69.14 & 84.10 \\
\hline 6 & 152.30 & 92.50 & 59.03 & 77.79 \\
\hline 7 & 168.95 & 83.90 & 70.10 & 66.27 \\
\hline 8 & 165.23 & 93.14 & 69.60 & 88.85 \\
\hline 9 & 153.77 & 81.58 & 58.23 & 84.51 \\
\hline 10 & 151.09 & 73.23 & 73.75 & 68.07 \\
\hline $\begin{array}{c}\text { Selective } \\
\text { average }\end{array}$ & 157.94 & 83.77 & 63.40 & 82.46 \\
\hline $\begin{array}{c}\text { Meansquare } \\
\text { value }\end{array}$ & 5.84 & 8.74 & 6.52 & 10.93 \\
\hline \multicolumn{4}{|c}{} \\
\hline \multicolumn{4}{|c|}{}
\end{tabular}

Here is a summary table 6 of the probability calculation of financial state levels for Example 2.

Table 6. Results of calculation of probabilities of financial stability levels for example 2

\begin{tabular}{|c|c|c|c|}
\hline Financial indicators & $\begin{array}{c}\text { Mean } \\
\text { standa } \\
\text { rd }\end{array}$ & $\begin{array}{c}\text { Mean } \\
\text { standar } \\
\text { d } \\
\text { deviatio } \\
\text { n } \\
\end{array}$ & 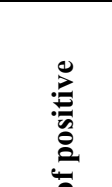 \\
\hline Inventory and costs $\mathrm{SaC}$ & 154 & 5.84 & \\
\hline Own Working Capital $O W C$ & 83 & 8.74 & \\
\hline long-term liabilities $L D C$ & 63 & 6.52 & 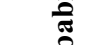 \\
\hline Short term liabilities $S D C$ & 82 & 10.00 & ?ํㄹ \\
\hline Working capital WC & 147 & 9.89 & 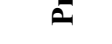 \\
\hline All funding sources TFS & 229 & 15.32 & \\
\hline $\begin{array}{l}\text { Surplus/shortage of own working capital } \\
\text { OWC }-\mathrm{SaC}\end{array}$ & -70 & 12.41 & 0 \\
\hline Surplus/lack of working capital WC $-\mathrm{SaC}$ & -6 & 13.23 & 0.30 \\
\hline $\begin{array}{l}\text { Surplus/lack of TFS funding sources } T F S- \\
\mathrm{SaC}\end{array}$ & 75 & 16.50 & $\begin{array}{c}0.99999 \\
7\end{array}$ \\
\hline
\end{tabular}

The results of Table 6 show that by the end of the current period, the probability of absolute stability is zero, the probability of normal stability is 0.3 , and the probability of unstable financial condition is almost 1 . 


\section{Conclusion}

In the event that market conditions are uncertain, it is proposed to use a probabilistic approach to assess the level of financial sustainability during the current period to forecast the financial condition of the enterprise at the end of that period. It is assumed that the main financial indicators for determining the financial condition: the amount of reserves and costs, the amount of own working capital, the values of long-term and short-term debts are normally distributed random values, the average and mean square deviation of which are estimated by selective average and selective mean square deviations. Formulas are built for calculation of selective average and selective mean-square deviations of indicators of surplus/deficiencies on own working capital, on amount of working capital and sum of all sources of financing and on known formulas probabilities of positive of specified indicators are calculated.

\section{References}

1. I. Avlasenko, L. Avlasenko, I. Peshkhoev, Yu. Podkolzin, O. Savelyeva, Enterprise growth simulation model, E3S Web of Conferences, 175, 12006 (2020) DOI: https://doi.org/10.1051/e3sconf/202017512006

2. I. M. Peshkhoev, I. V. Avlasenko, O. V. Panfilova, Y. V. Podkolzin, O. G. Savelyeva, The Methods of Evaluation of Investment Project with Undetermined Parameters. Perspectives on the Use of New Information and Communication Technology (ICT) in the Modern Economy. ISC 2017. Advances in Intelligent Systems and Computing, Springer, Cham, 726, 67-71 (2018) DOI: https://doi.org/10.1007/978-3-319-90835-9_8

3. V. V. Lysenko, Assessment of risks of financial stability of enterprises based on models of distribution of probabilities of dynamics of financial indicators (in Russ.), Theoretical economy, 3, 7 1-80 (2018)

4. N. Egorova, Models and methods for analysis of small enterprises' sustainable development. Economics and the Mathematical Methods, 56(3), 79-90 (2020) DOI: $10.31857 / \mathrm{S} 042473880010548-1$

5. N. E. Egorova, A. F. Akhmetshin, Methods for modelling sustainable development strategy in application to small enterprises, International Journal of Advanced Biotechnology and Research (IJBR). ISSN 0976-2612, Online ISSN 2278-599X, 8(1), 1-16 (2017)

6. A. A. Yakushev, Yu. V. Lysenko, Economic-Mathematical Modeling of the Enterprise Solvency. Risk Assessment, International Journal of Economics and Financial Issues, 8(6), 157-166 (2018) DOI: https://doi.org/10.32479/ijefi.7178

7. N. V. Babintseva, The method of complex comparative rating assessment of solvency and financial stability of the enterprise. Journal of Economics and Entrepreneurship, 11(52-4), 609-612 (2014)

8. A. N. Baranov, Liquidity and solvency management of the enterprise. Journal of Economics and Society, 6(37), 228-231 (2017)

9. T. A. Vishnyakova, Methods and models for assessing the financial stability of a Corporation, Scientific and methodological electronic journal «Concept», 8 (2018)

10. T. V. Zhukova, O. V. Panfilova, I. V. Avlasenko, L. M. Avlasenko, A. V. Belousova Deformations of the Global Financial System in the Conditions of Globalization. International Conference Project "The future of the Global Financial System: Downfall 
of Harmony" ISC 2018: The Future of the Global Financial System: Downfall or Harmony, 774-782 (2018)

11. I. G. Ushachev, Main directions of the strategy for sustainable socio-economic development of the agro-industrial complex of Russia, 6, 4-24 (2017)

12. V. V. Podshivalova, Current aspects of state regulation of agricultural machinery imports. Economics and management: analysis of development trends and prospects, 25 (2016)

13. A. K. Subaeva, Methodology of Evaluation of the Structure of Material and Technical Base of Agro-Industrial Complex and Analysis of Competitive Environment. Scientific and Methodological Electronic Journal "Concept.", 3, 3186- 3190 (2013)

14. A. I. Chernikova, A. B. Vishnyakova, Assessment of solvency based on liquidity indicators of industrial enterprises. Science of the XXI Century: Actual Directions of Development, 2(2), 207-212 (2016)

15. I. G. Ushachev, A. F. Serkov, V. V. Maslova, V. S. Chekalin, The growth and development of agro-industrial production needs an integrated approach, 4, 4-15 (2016) 